\title{
The Characteristics of Continuing Professional Education Systems in the Health Professions in Canada
}

\author{
Vernon Curran, Fran Kirby, and Lisa Fleet \\ Memorial University
}

\begin{abstract}
Mandatory continuing education (MCE) has become widely accepted across many professions and jurisdictions in Canada as a recredentialing mechanism. MCE is defined as continuing professional education (CPE) courses and/or programs, beyond the entry-level educational requirements, required by a licensure board, professional organization, or the workplace in order to maintain competence or retain licensure, certification, and/or employment. The purpose of this paper is to summarize the nature and characteristics of the CPE systems of the major health care professions in Canada. Overall, mandatory systems of CPE are increasing among allied health professional groups in Canada. This introduces significant opportunities for pro-
\end{abstract}

\begin{abstract}
RÉSUMÉ
L'éducation permanente obligatoire (ÉPO) est devenue largement acceptée dans un grand nombre de professions et de juridictions au Canada comme mécanisme de réaccréditation. Par ÉPO, on entend les cours et/ou programmes d'éducation professionnelle permanente (ÉPP) qui vont au-delà des exigences minimales d'éducation, requis par une commission d'autorisation $\mathrm{d}^{\prime}$ exercer, un organisme professionnel, ou un milieu de travail en vue de maintenir des compétences ou retenir une licence, une certification et/ou un emploi. Cet article a pour but de résumer la nature et les caractéristiques des systèmes d'ÉPP des professions principales en soins de la santé au Canada. Sur l'ensemble, le nombre de systèmes obligatoires d'ÉPP est à la hausse parmi
\end{abstract}

Canadian Journal of University Continuing Education

Vol. 32, No. 1, Spring 2006

pp. 47-82 
viders of CPE for the health professions. Important trends appear to include an increase in distance education formats, an increase in collaborative arrangements between providers, and an increase in the use of CPE to regulate practice. les groupes de professions paramédicales. Cela permet des occasions importantes pour les fournisseurs d'EPP aux professions de la santé. Les tendances importantes semblent comprendre de plus en plus les formats d'éducation à distance, un plus grand nombre d'ententes de collaboration entre fournisseurs, et une augmentation de l'utilisation des ÉPP pour réglementer la pratique.

\section{INTRODUCTION}

Over the years, increased importance has been placed on continuing professional education (CPE) as a means for promoting continuing competency in the health professions (Cervero, 2000). Mandatory continuing education (MCE) has also become widely accepted across professions and jurisdictions as a re-credentialing mechanism. Both have been influenced largely by increased societal expectations for greater accountability amongst the professions in the maintenance of professional competence (Grossman, 1998). Legislative bodies and professional associations striving to provide this increased accountability have turned to MCE as a strategy of choice.

The introduction and expansion of MCE systems in the health professions have many implications. Proponents of MCE have argued that, in order to remain competent, professionals need to participate in regular CPE activities to update their knowledge, skills, and abilities (Brockett \& LeGrand, 1992; Queeney \& English, 1994) and, in order to ensure the participation of all professionals, CPE should be mandated as a condition of continued practice. Proponents have also argued that MCE can lead to more efficient, effective practice, as well as weed out incompetent professionals. Indeed, without an MCE mandate, those needing CPE may be the least likely to pursue it. As a result, MCE may motivate participation and commitment among professional "laggards" and promote a renewed enthusiasm for maintaining competence (Brockett \& LeGrand, 1992; Queeney \& English, 1994).

Opponents, however, suggest that MCE has not substantially increased the participation rates of practitioners. Studies of CPE-mandated participation of physicians and nurses observed no appreciable changes in time spent in CPE activities within either of these groups (Kerka, 1994). Another fundamental line of criticism suggests that no conclusive evidence exists to indi-

Revue canadienne de l'éducation permanente universitaire

Vol. 32, No 1, primtemps 2006 
cate that participation in MCE ensures effective or competent performance (Davis, Thomson, Oxman, \& Haynes, 1995). Education does not ensure competence and learning cannot be legislated (Brockett \& LeGrand, 1992; Queeney \& English, 1994). Attendance at mandated CPE programs, in reality, is only a measure of time spent in learning activities.

A more important argument made by opponents of MCE relates to "access." Educational opportunities are not readily and equally available to all who may be required to participate in them. They are not available in formats, locations, time frames, and price ranges that make them accessible to the full range of practitioners. Financial implications can be substantial and especially troublesome for individuals, small organizations, and solo practitioners. For rural health-care professionals, receiving and participating in CPE can present a substantial challenge (Byers, Hilgenberg, \& Rhodes, 1996; Latchem \& Rapley, 1992). Geographic distance not only contributes to the cost of attending selected activities but also increases the time away from family and work. Arranging the necessary locum or replacement coverage also makes "getting away" difficult.

The purpose of the study presented in this article was to review the nature and characteristics of CPE systems in the health professions in Canada. This review provides an overall description of the regulatory characteristics of CPE systems, including whether they are mandatory or voluntary, and specific CPE requirements. The health professions examined were family physicians, medical specialists, registered nurses, licensed practical nurses, pharmacists, psychologists, social workers, occupational therapists, physiotherapists, speech language pathologists and audiologists, medical laboratory technologists, and medical radiation technologists. A detailed comparative summary of the characteristics of these various CPE systems is provided later in the article.

\section{Continuing Professional Education}

According to Houle (1980), a key characteristic of professionalization is the formal means that are normally used to assess the capacity of individual practitioners to perform their duties at an acceptable level and to license those who are qualified to do so. The recognition of the need for formal credentialing systems was a major element in the evolution from individualized and unregulated practice to modern professionalism (Houle, 1980). Formalized regulatory credentialing systems established basic levels of competence that individuals entering any profession must attain before being allowed to work as a fully qualified practitioner. Re-credentialing systems developed as well, as a means for regularly monitoring professional practice. Also known as re-accreditation, re-licensure, and re-certification, these 
systems are adaptations of the regulatory mechanisms that were established to govern entry into a profession. As a result of advances in knowledge and technology, as well as societal demands for accountability and consumer protection, the number of jurisdictions requiring MCE for various professions has significantly increased over the years (Queeney \& English, 1994). Cervero (2000) suggested that CPE is being used more frequently as a tool for re-credentialing and regulating professional practice.

CPE encompasses all of the formal, informal, and non-formal learning activities that are intended to enhance and maintain the competencies of professionals. This learning takes place once a professional has completed pre-service education and entered practice. Becoming a professional also implies a commitment to continuing one's education. A fundamental principle of CPE is lifelong learning, whereby professionals pursue knowledge and skills to maintain competency in their field of practice. The "ideal" of every profession is that each professional maintains a continuing concern over his or her own education and participates in CPE throughout a lifetime of practice. In many professions, such a commitment is explicit in a code of ethics or practice.

\section{Mandatory Continuing Education}

Mandatory continuing education is now widely accepted across professions and jurisdictions in Canada as a re-credentialing mechanism; in these professions and among these jurisdictions, it is linked with re-licensure, recertification, or re-registration. MCE is defined as continuing professional education courses and/or programs that go beyond the entry-level educational requirements taken for credit, as required by a licensure board, professional organization, or the workplace, in order to maintain competence or retain licensure, certification, and/or employment. These requirements may be expressed in terms of contact hours (e.g., 40 hours of CPE activity) per annual basis (Cervero, 2000).

The impetus for MCE has come from governments and licensing bodies, professional associations, and consumer groups. An increased level of consumer awareness and greater pressure for accountability has brought with it a growing realization that competence must be addressed and that some demonstration of competence is needed in many professions. Legislative bodies and professional associations striving to provide increased accountability most frequently turn to MCE as their strategy of choice, considering it the best alternative available for meeting their responsibility to ensure provision of competent services to society.

According to Nowlen (1988), there are three models of, or approaches to, CPE. The update model promotes information-intensive, "highly didactic short

Revue canadienne de l'éducation permanente universitaire

Vol. 32, No 1, primtemps 2006 
courses [with the] central aim of keeping professionals up-to-date in their practices" (p. 24). The update model, however, is grounded in a "centuries old positivist paradigm in which knowledge is thought to be an external commodity, a paradigm in which most of us are not taught to be the creators of knowledge used in practice, but merely consumers" (Mott, 1998, p. 672). Mott (2000) maintained that practitioners who use the update model exclusively can never keep up with the ever-expanding and quickly obsolete knowledge base of professional practice (p. 25).

In the competence model, "current and relevant knowledge must be combined with other skills (such as critical thinking or interpersonal relationship skills), personal traits and characteristics (such as initiative or a sense of ethics), an individual schema or self-image as a professional, and self-direction or a motive that serves to direct one's actions in practice" (Mott, 2000, p. 25). The goal is to build curricula based on competencies required in specific work settings and enhance this through relevant exercises, role-playing, case studies, and problem solving. Although this model provides a good picture of what good practice is, it does not provide a picture of what it is not or might be (Mott, 2000).

The third model, the performance model, is based on "three basic precepts of professional practice: first, practicing professionals are individuals, influenced by their environments, self-images, roles, and values; second, professionals practice in complex networks of interdependent systems; and third, complex performance cannot be significantly affected by any single form of intervention" (Mott, 2000, p. 25). This model engages professionals in critical self-assessment and incorporates principles of both the update and the competence models. It also places greater emphasis on the needs of the professional within his or her context of practice and promotes the notion of CPE as support for practitioners within their practice environment.

As previously noted, most systems of accounting for CPE are based on clock hours, that is, the number of credit hours an individual accumulates as evidence of attendance or participation in certain CPE activities. Such a system is reported as administratively efficient and manageable, but critics argue that measures of extent of participation carry no assurance that desired changes in participants' competence or performance have occurred. This is a fundamental challenge confronting the CPE field.

Another criticism of a participation-based standard is its tendency to limit CPE to the update model, or the "instructional" mode. In an update model, the scope of continuing education is narrowed so that "keeping up to date" is the only purpose. As a remedy, a small number of professions have recommended self-assessment tools, and some have introduced self-directed learning activities as an integral component of continuing competency plans. Proactive MCE models are seen to be those that combine evaluation meth-

Canadian Journal of University Continuing Education

Vol. 32, No. 1, Spring 2006 
ods, such as continuing education, peer evaluation, and professional portfolios, with other professional improvement goals, such as specialty certification (Grossman, 1998).

\section{Providers of Continuing Professional Education}

The responsibility for providing CPE is assumed by a wide variety of organizations, institutions, and individuals, the most common of which are professional associations and formal educational institutions. CPE opportunities are also developed and implemented by independent education and training brokers, by manufacturers and suppliers of professional supplies and equipment, and by professionals themselves, either individually or in small groups, as well as in employment settings. Cervero (2000) identified universities and professional associations as important providers, with an increasing number of programs being offered in distance education formats. Most universities sponsor continuing education programs either through various professional schools, such as medicine, social work, and engineering, or through a university-wide continuing education unit. The major if not primary function of many professional associations is the provision of continuing education. More than 5,000 American and Canadian associations, and many more state, provincial, and local associations, are either organized independently or affiliated with a national body (Cervero, 2000).

Cervero (2000) also suggested that the number of collaborative arrangements amongst providers, especially between universities and workplaces, has increased. Studies of universities and professional schools have indicated that anywhere from $60 \%$ to $85 \%$ of their programs involve some form of collaboration. Similar studies have found that about $50 \%$ of professional associations and $85 \%$ of independent providers engage in collaborative programming (Cervero, 2000).

\section{Study Methodology}

Key informant interviews, a web-based survey, website reviews, and follow-up telephone consultations were conducted to gather information on the CPE systems of the major health professions in Canada. The interviews were conducted with representatives of national professional, academic, and health administration organizational bodies. Interviewees included senior administrators or directors of professional bodies responsible for accrediting or administering CPE programs (e.g., College of Family Physicians of Canada), as well as national health professional associations (e.g., Canadian Nurses Association), national organizations representing health care institu-

Revue canadienne de l'éducation permanente universitaire

Vol. 32, No 1, primtemps 2006 
tions (e.g., Canadian Healthcare Association), and academic institutions (e.g., Association of Faculties of Medicine of Canada). Interviews were conducted by telephone and tape-recorded with the permission of the informant. Informants were asked to describe the general nature of the continuing education system in Canada for their respective profession, including the regulatory characteristics and jurisdictional responsibility. Key informant interviews were conducted with 21 individuals $(n=21)$, representing a variety of professional bodies and associations. The key informant interview script is presented in Appendix A.

A web-based survey (Appendix B) was developed and distributed to provincial academic institutions, health professional associations, and regulatory bodies. The survey was designed using a combination of closed- and openended-question types. Survey respondents were asked to describe the general nature of the continuing education system at a provincial level for their respective profession. As part of this description, they were asked to describe the regulatory characteristics of the CPE system and its requirements.

Surveys were posted in both English and French during August 2004. In all, 389 email requests, which also described the purpose of the study, were sent to potential respondents; 152 responses were received for a response rate of $39.1 \%$.

Website reviews were used to verify and validate the information that was collected through the interviews and surveys. The websites of the national and provincial health professional associations and the national and provincial health professional and regulatory bodies were all reviewed. These websites were scanned for documents and information related to continuing education, professional development, education, continuing competence, licensure, registration, and standards of practice. 


\section{StUdy Results}

Table 1 identifies the specific professions included in the CPE review. The information presented in the article represents the status of CPE systems in Canada as of October 2004.

Table 1: Professions Reviewed

- family physicians

- medical specialists

- registered nurses

- licensed practical nurses

- pharmacists

- psychologists

- social workers

- occupational therapists

- physiotherapists

- speech language pathologists and audiologists

- medical laboratory technologists

- medical radiation technologists

\section{National Continuing Professional Education Systems}

Canadian family physicians, medical specialists, and speech language pathologists and audiologists have mandatory CPE systems that are regulated and monitored at a national level. CPE for each of these professions is associated with re-certification versus re-licensure. In contrast to a statutory or regulatory requirement, certification is a voluntary program that confers recognition of excellence. Each of these professions also has a formalized infrastructure that oversees and monitors the level and type of CPE activities required by its members. Registered nurses in Canada are able to participate in a voluntary specialty certification credentialing program offered by the Canadian Nurses Association (CNA).

\section{Family Physicians}

Family physicians registered as members of the College of Family Physicians of Canada (CFPC) are required to participate in mandatory CPE. The CFPC continuing professional education system is known as Mainpro (Maintenance of Proficiency/Maintien de la compétence professionnelle). Every five years, CFPC members must complete 250 credits, 125 of which must be part of an accredited continuing medical education (CME) format

Revue canadienne de l'éducation permanente universitaire Vol. 32, No 1, primtemps 2006 
(Mainpro-M1 and/or Mainpro-C credits). The remaining credits can be of a non-accredited CME nature (Mainpro-M2 credits). The CFPC follows a selfreporting monitoring structure. Members are responsible for maintaining their own CME records and can accumulate credits at any time during the five-year cycle, although they are encouraged to plan activities throughout the cycle. Regular reporting is not required; members may report their credits at any time by mail, fax, email, telephone, or online through a secure members-only access area on the CFPC Web site.

\section{Medical Specialists}

Medical specialists in Canada who are Fellows (or members) of the Royal College of Physicians and Surgeons of Canada (RCPSC) are required to participate in mandatory CME for re-certification. Medical specialists are expected to adhere to a five-year cycle. RCPSC's continuing medical education system is known as Maincert (Maintenance of Certification). A sixsection framework outlines members' options for CME. They can use this framework to design their own program of professional development, based on their practice needs and preferred learning methods. Members must complete 400 credits over the five-year cycle. Like the CFPC, the RCPSC has a self-reporting monitoring structure, which members are expected to use to submit their CME hours on an annual basis. RCPSC randomly audits approximately $3 \%$ of its members annually and asks them to provide documentation as evidence of their CME activities.

Speech Language Pathologists and Audiologists

Licensure or registration to practise as a speech language pathologist or audiologist is only required in Alberta, Saskatchewan, Manitoba, Ontario, Québec, and New Brunswick. However, approximately $70 \%$ to $80 \%$ of speech language pathologists and audiologists in Canada are certified by the Canadian Association of Speech Language Pathologists and Audiologists (CASLPA). CASLPA requires members to complete and report a minimum of 45 hours of continuing education equivalents (CEEs) over a three-year cycle. For those certified by CASLPA, the CPE system is regulated and monitored at the national level. Monitoring occurs on an annual basis and the onus is on members to submit their list of activities and hours completed.

Registered Nurses (RNs)

Registered nurses (RNs) in Canada are able to obtain voluntary specialty certification through the Canadian Nurses Association's (CNA) Certification Program. Specialty certification confirms that the RN has demonstrated competence in a nursing specialty by meeting predetermined standards of that specialty. Currently, there are 17 designated areas of nursing in the 
CNA Certification Program. The initial certification credential is valid for five years, after which participants must be re-certified to maintain the credential. To be eligible, RNs must meet the hours of experience required for recertification and either rewrite the certification exam or complete a minimum of 100 hours of continuous learning activities in their nursing specialty during the five-year certification term.

A number of activities can be counted as continuous learning hours. For instance, university courses taken in order to complete an undergraduate degree, a Master's degree, or a PhD in nursing can count toward re-certification, but content must relate to the nursing specialty. RNs also have the option of using non-nursing courses that focus on their specialty area, as well as time spent attending conferences related to their specialty area, as continuous learning hours. Participation in this program is regulated and monitored at the national level by the CNA. Those applying for re-certification are required to complete and submit the appropriate application form and then either rewrite the certification exam or submit a record of their continuous learning activities. The CNA conducts a random audit of approximately $10 \%$ of candidates applying for re-certification.

\section{Provincial Continuing Professional Education Systems}

CPE systems for registered nurses, licensed practical nurses, pharmacists, psychologists, social workers, occupational therapists, physiotherapists, medical laboratory technologists, and medical radiation technologists in Canada are organized at a provincial level. Table 2 presents an overview of provincial $\mathrm{CPE}$ systems across each of these professions, as well as the requirements for each profession in each province.

Registered Nurses (RNs)

British Columbia, Saskatchewan, Manitoba, Ontario, Nova Scotia, and Prince Edward Island, as well as Northwest Territories and Nunavut, have legislation that mandates RNs participate in some form of CPE for re-registration (or re-licensure). The majority of these mandatory CPE systems are based on a program of continuing competency, the fundamental principles of which are self-directedness and autonomy in the identification of personal learning needs and participation in selective educational activities to address those needs. Learning activities may be formal (e.g., courses, in-services, workshops) or non-formal (e.g., gathering information via the literature, the internet, colleagues, clients). Each regulatory or licensing body monitors individuals to ensure that they have met continuing competency requirements at the time of registration renewal, and they must submit signed declarations signifying that they have done so. Random audits are conducted in some provinces to confirm compliance.

Revue canadienne de l'éducation permanente universitaire

Vol. 32, No 1, primtemps 2006 
Table 2: Provincial CPE Systems

\begin{tabular}{|c|c|c|c|c|}
\hline Profession & Province & 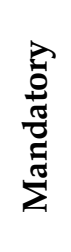 & 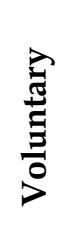 & 幽 \\
\hline \multirow{12}{*}{$\begin{array}{l}\text { Registered Nurses } \\
\text { (RNs) }\end{array}$} & British Columbia & $X$ & & yearly cycle \\
\hline & Alberta & & $X$ & $\begin{array}{c}\text { not } \\
\text { applicable }\end{array}$ \\
\hline & Saskatchewan & $X^{*}$ & & yearly cycle \\
\hline & Manitoba & $x$ & & yearly cycle \\
\hline & Ontario & $X$ & & yearly cycle \\
\hline & Québec & & $X$ & $\begin{array}{c}\text { not } \\
\text { applicable }\end{array}$ \\
\hline & New Brunswick & & $X$ & $\begin{array}{c}\text { not } \\
\text { applicable }\end{array}$ \\
\hline & Nova Scotia & $X$ & & yearly cycle \\
\hline & $\begin{array}{l}\text { Prince Edward } \\
\text { Island }\end{array}$ & $X$ & & yearly cycle \\
\hline & $\begin{array}{l}\text { Newfoundland } \\
\text { and Labrador }\end{array}$ & & $X$ & $\begin{array}{c}\text { not } \\
\text { applicable }\end{array}$ \\
\hline & $\begin{array}{l}\text { Northwest } \\
\text { Territories/ } \\
\text { Nunavut }\end{array}$ & $X$ & & yearly cycle \\
\hline & Yukon & & $X$ & $\begin{array}{c}\text { not } \\
\text { applicable }\end{array}$ \\
\hline
\end{tabular}

* only for those who are licensed (licensure is voluntary) 


\begin{tabular}{|c|c|c|c|c|}
\hline Profession & Province & 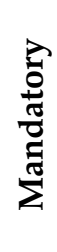 & 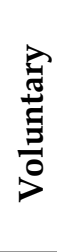 & w \\
\hline \multirow{13}{*}{$\begin{array}{l}\text { Licensed Practical } \\
\text { Nurses (LPNs) }\end{array}$} & British Columbia & $X$ & & 5 -year cycle \\
\hline & Alberta & $X$ & & yearly cycle \\
\hline & Saskatchewan & $X$ & & yearly cycle \\
\hline & Manitoba & & $x$ & $\begin{array}{c}\text { not } \\
\text { applicable }\end{array}$ \\
\hline & Ontario & $X$ & & yearly cycle \\
\hline & Québec & & $X$ & $\begin{array}{c}\text { not } \\
\text { applicable }\end{array}$ \\
\hline & New Brunswick & & $X$ & $\begin{array}{c}\text { not } \\
\text { applicable }\end{array}$ \\
\hline & Nova Scotia & & $X$ & $\begin{array}{c}\text { not } \\
\text { applicable }\end{array}$ \\
\hline & $\begin{array}{l}\text { Prince Edward } \\
\text { Island }\end{array}$ & & $X$ & $\begin{array}{c}\text { not } \\
\text { applicable }\end{array}$ \\
\hline & $\begin{array}{l}\text { Newfoundland } \\
\text { and Labrador }\end{array}$ & & $X$ & $\begin{array}{c}\text { not } \\
\text { applicable }\end{array}$ \\
\hline & $\begin{array}{l}\text { Northwest } \\
\text { Territories }\end{array}$ & & $X$ & $\begin{array}{c}\text { not } \\
\text { applicable }\end{array}$ \\
\hline & Nunavut & & $X$ & $\begin{array}{c}\text { not } \\
\text { applicable }\end{array}$ \\
\hline & Yukon & & $X$ & $\begin{array}{c}\text { not } \\
\text { applicable }\end{array}$ \\
\hline
\end{tabular}

Revue canadienne de l'éducation permanente universitaire Vol. 32, No 1, primtemps 2006 


\begin{tabular}{|c|c|c|c|c|}
\hline Profession & Province & 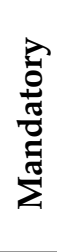 & 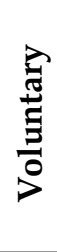 & 现 \\
\hline \multirow{13}{*}{ Pharmacists } & British Columbia & $X$ & & 6-year cycle \\
\hline & Alberta & $X$ & & $\begin{array}{c}\text { yearly cycle; } 15 \\
\text { continuing educa- } \\
\text { tion units (CEUs) }\end{array}$ \\
\hline & Saskatchewan & $X$ & & $\begin{array}{c}\text { yearly cycle; } 15 \\
\text { CEUs }\end{array}$ \\
\hline & Manitoba & $X$ & & $\begin{array}{l}\text { completion of a } \\
\text { minimum of } 5 \\
\text { major learning } \\
\text { projects within a } \\
\text { 5-year cycle }\end{array}$ \\
\hline & Ontario & $X$ & & 5-year cycle \\
\hline & Québec & & $X$ & $\begin{array}{c}\text { not } \\
\text { applicable }\end{array}$ \\
\hline & New Brunswick & $X$ & & $\begin{array}{l}15 \text { CEUs per } \\
\text { yearly cycle }\end{array}$ \\
\hline & Nova Scotia & $X$ & & $\begin{array}{l}15 \text { CEUs per } \\
\text { yearly cycle }\end{array}$ \\
\hline & $\begin{array}{l}\text { Prince Edward } \\
\text { Island }\end{array}$ & $X$ & & $\begin{array}{l}15 \text { CEUs per } \\
\text { yearly cycle }\end{array}$ \\
\hline & $\begin{array}{l}\text { Newfoundland } \\
\text { and Labrador }\end{array}$ & $X$ & & $\begin{array}{l}15 \text { CEUs per } \\
\text { yearly cycle }\end{array}$ \\
\hline & $\begin{array}{l}\text { Northwest } \\
\text { Territories }\end{array}$ & & $X$ & $\begin{array}{c}\text { not } \\
\text { applicable }\end{array}$ \\
\hline & Nunavut & & $X$ & $\begin{array}{c}\text { not } \\
\text { applicable }\end{array}$ \\
\hline & Yukon & & $X$ & $\begin{array}{c}\text { not } \\
\text { applicable }\end{array}$ \\
\hline
\end{tabular}




\begin{tabular}{|c|c|c|c|c|}
\hline Profession & Province & 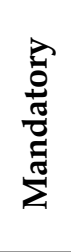 & 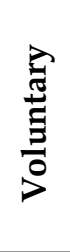 & 埢 \\
\hline \multirow[t]{13}{*}{ Psychologists } & British Columbia & $X$ & & $\begin{array}{l}35 \text { hours per } \\
\text { yearly cycle }\end{array}$ \\
\hline & Alberta & & $X$ & $\begin{array}{c}\text { not } \\
\text { applicable }\end{array}$ \\
\hline & Saskatchewan & & $x$ & $\begin{array}{c}\text { not } \\
\text { applicable }\end{array}$ \\
\hline & Manitoba & & $X$ & $\begin{array}{c}\text { not } \\
\text { applicable }\end{array}$ \\
\hline & Ontario & $X$ & & 2-year cycle \\
\hline & Québec & & $x$ & $\begin{array}{c}\text { not } \\
\text { applicable }\end{array}$ \\
\hline & New Brunswick & & $X$ & $\begin{array}{c}\text { not } \\
\text { applicable }\end{array}$ \\
\hline & Nova Scotia & & $X$ & $\begin{array}{c}\text { not } \\
\text { applicable }\end{array}$ \\
\hline & $\begin{array}{l}\text { Prince Edward } \\
\text { Island }\end{array}$ & $x$ & & $\begin{array}{l}40 \text { hours of } \mathrm{CPE} \\
\text { per yearly cycle }\end{array}$ \\
\hline & $\begin{array}{l}\text { Newfoundland } \\
\text { and Labrador }\end{array}$ & & $X$ & $\begin{array}{c}\text { not } \\
\text { applicable }\end{array}$ \\
\hline & $\begin{array}{l}\text { Northwest } \\
\text { Territories }\end{array}$ & & $X$ & $\begin{array}{c}\text { not } \\
\text { applicable }\end{array}$ \\
\hline & Nunavut & & $x$ & $\begin{array}{c}\text { not } \\
\text { applicable }\end{array}$ \\
\hline & Yukon & & $X$ & $\begin{array}{c}\text { not } \\
\text { applicable }\end{array}$ \\
\hline
\end{tabular}




\begin{tabular}{|c|c|c|c|c|}
\hline Profession & Province & 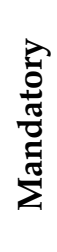 & 胥 & سֶّ \\
\hline \multirow[t]{13}{*}{ Social Workers } & British Columbia & & $X$ & $\begin{array}{c}\text { not } \\
\text { applicable }\end{array}$ \\
\hline & Alberta & $X$ & & $\begin{array}{l}40 \text { professional } \\
\text { development } \\
\text { credits per yearly } \\
\text { cycle }\end{array}$ \\
\hline & Saskatchewan & $X$ & & $\begin{array}{c}40 \text { CPE hours per } \\
\text { yearly cycle }\end{array}$ \\
\hline & Manitoba & $X^{*}$ & & $\begin{array}{l}40 \text { hours of } \mathrm{CPE} \\
\text { per yearly cycle }\end{array}$ \\
\hline & Ontario & & $X$ & $\begin{array}{c}\text { not } \\
\text { applicable }\end{array}$ \\
\hline & Québec & & $X$ & $\begin{array}{c}\text { not } \\
\text { applicable }\end{array}$ \\
\hline & New Brunswick & $X$ & & $\begin{array}{l}40 \text { CPE credits per } \\
\text { yearly cycle }\end{array}$ \\
\hline & Nova Scotia & $X$ & & $\begin{array}{l}40 \text { hours of } \mathrm{CPE} \\
\text { per yearly cycle }\end{array}$ \\
\hline & $\begin{array}{l}\text { Prince Edward } \\
\text { Island }\end{array}$ & & $X$ & $\begin{array}{c}\text { not } \\
\text { applicable }\end{array}$ \\
\hline & $\begin{array}{l}\text { Newfoundland } \\
\text { and Labrador }\end{array}$ & $X$ & & $\begin{array}{l}40 \text { CPE credits per } \\
\text { yearly cycle }\end{array}$ \\
\hline & $\begin{array}{l}\text { Northwest } \\
\text { Territories }\end{array}$ & & $X$ & $\begin{array}{c}\text { not } \\
\text { applicable }\end{array}$ \\
\hline & Nunavut & & $X$ & $\begin{array}{c}\text { not } \\
\text { applicable }\end{array}$ \\
\hline & Yukon & & $X$ & $\begin{array}{c}\text { not } \\
\text { applicable }\end{array}$ \\
\hline
\end{tabular}




\begin{tabular}{|c|c|c|c|c|}
\hline Profession & Province & 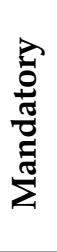 & 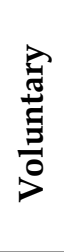 & 幽 \\
\hline \multirow{13}{*}{$\begin{array}{l}\text { Occupational } \\
\text { Therapists }\end{array}$} & British Columbia & & $X$ & $\begin{array}{c}\text { not } \\
\text { applicable }\end{array}$ \\
\hline & Alberta & & $X$ & $\begin{array}{c}\text { not } \\
\text { applicable }\end{array}$ \\
\hline & Saskatchewan & & $X$ & $\begin{array}{c}\text { not } \\
\text { applicable }\end{array}$ \\
\hline & Manitoba & & $X$ & $\begin{array}{c}\text { not } \\
\text { applicable }\end{array}$ \\
\hline & Ontario & $X$ & & yearly cycle \\
\hline & Québec & & $X$ & $\begin{array}{c}\text { not } \\
\text { applicable }\end{array}$ \\
\hline & New Brunswick & & $X$ & $\begin{array}{c}\text { not } \\
\text { applicable }\end{array}$ \\
\hline & Nova Scotia & & $X$ & $\begin{array}{c}\text { not } \\
\text { applicable }\end{array}$ \\
\hline & $\begin{array}{l}\text { Prince Edward } \\
\text { Island }\end{array}$ & $X$ & & $\begin{array}{l}10 \text { CPE credits per } \\
\text { yearly cycle }\end{array}$ \\
\hline & $\begin{array}{l}\text { Newfoundland } \\
\text { and Labrador }\end{array}$ & & $X$ & $\begin{array}{c}\text { not } \\
\text { applicable }\end{array}$ \\
\hline & $\begin{array}{l}\text { Northwest } \\
\text { Territories }\end{array}$ & & $X$ & $\begin{array}{c}\text { not } \\
\text { applicable }\end{array}$ \\
\hline & Nunavut & & $X$ & $\begin{array}{c}\text { not } \\
\text { applicable }\end{array}$ \\
\hline & Yukon & & $X$ & $\begin{array}{c}\text { not } \\
\text { applicable }\end{array}$ \\
\hline
\end{tabular}




\begin{tabular}{|c|c|c|c|c|}
\hline Profession & Province & 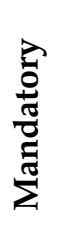 & 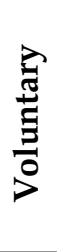 & 幽 \\
\hline \multirow[t]{13}{*}{ Physiotherapists } & British Columbia & & $X$ & $\begin{array}{c}\text { not } \\
\text { applicable }\end{array}$ \\
\hline & Alberta & & $x$ & $\begin{array}{c}\text { not } \\
\text { applicable }\end{array}$ \\
\hline & Saskatchewan & & $x$ & $\begin{array}{c}\text { not } \\
\text { applicable }\end{array}$ \\
\hline & Manitoba & & $X$ & $\begin{array}{c}\text { not } \\
\text { applicable }\end{array}$ \\
\hline & Ontario & $X$ & & yearly cycle \\
\hline & Québec & & $x$ & $\begin{array}{c}\text { not } \\
\text { applicable }\end{array}$ \\
\hline & New Brunswick & & $X$ & $\begin{array}{c}\text { not } \\
\text { applicable }\end{array}$ \\
\hline & Nova Scotia & & $X$ & $\begin{array}{c}\text { not } \\
\text { applicable }\end{array}$ \\
\hline & $\begin{array}{l}\text { Prince Edward } \\
\text { Island }\end{array}$ & $X$ & & $\begin{array}{l}10 \text { CPE credits per } \\
\text { yearly cycle }\end{array}$ \\
\hline & $\begin{array}{l}\text { Newfoundland } \\
\text { and Labrador }\end{array}$ & & $X$ & $\begin{array}{c}\text { not } \\
\text { applicable }\end{array}$ \\
\hline & $\begin{array}{l}\text { Northwest } \\
\text { Territories }\end{array}$ & & $X$ & $\begin{array}{c}\text { not } \\
\text { applicable }\end{array}$ \\
\hline & Nunavut & & $X$ & $\begin{array}{c}\text { not } \\
\text { applicable }\end{array}$ \\
\hline & Yukon & & $X$ & $\begin{array}{c}\text { not } \\
\text { applicable }\end{array}$ \\
\hline
\end{tabular}




\begin{tabular}{|c|c|c|c|c|}
\hline Profession & Province & 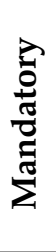 & 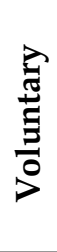 & 剀 \\
\hline \multirow{13}{*}{$\begin{array}{l}\text { Medical } \\
\text { Laboratory } \\
\text { Technologists }\end{array}$} & British Columbia & & $x$ & $\begin{array}{c}\text { not } \\
\text { applicable }\end{array}$ \\
\hline & Alberta & & $x$ & $\begin{array}{c}\text { not } \\
\text { applicable }\end{array}$ \\
\hline & Saskatchewan & $x$ & & $\begin{array}{l}\text { minimum of } 2 \\
\text { CPE credits or } \\
30 \text { contact hours } \\
\text { ( } 1 \mathrm{CPE} \text { credit is } \\
\text { equivalent to } 15 \\
\text { contact hours) } \\
\text { over } 5 \text {-year cycle }\end{array}$ \\
\hline & Manitoba & & $x$ & $\begin{array}{c}\text { not } \\
\text { applicable }\end{array}$ \\
\hline & Ontario & $x$ & & yearly cycle \\
\hline & Québec & & $X$ & $\begin{array}{c}\text { not } \\
\text { applicable }\end{array}$ \\
\hline & New Brunswick & & $x$ & $\begin{array}{c}\text { not } \\
\text { applicable }\end{array}$ \\
\hline & Nova Scotia & $X$ & & $\begin{array}{c}8 \text { CPE credits over } \\
\text { a 4-year cycle }\end{array}$ \\
\hline & $\begin{array}{l}\text { Prince Edward } \\
\text { Island }\end{array}$ & & $X$ & $\begin{array}{c}\text { not } \\
\text { applicable }\end{array}$ \\
\hline & $\begin{array}{l}\text { Newfoundland } \\
\text { and Labrador }\end{array}$ & & $X$ & $\begin{array}{c}\text { not } \\
\text { applicable }\end{array}$ \\
\hline & $\begin{array}{l}\text { Northwest } \\
\text { Territories }\end{array}$ & & $X$ & $\begin{array}{c}\text { not } \\
\text { applicable }\end{array}$ \\
\hline & Nunavut & & $X$ & $\begin{array}{c}\text { not } \\
\text { applicable }\end{array}$ \\
\hline & Yukon & & $x$ & $\begin{array}{c}\text { not } \\
\text { applicable }\end{array}$ \\
\hline
\end{tabular}

Revue canadienne de l'éducation permanente universitaire Vol. 32, No 1, primtemps 2006 


\begin{tabular}{|c|c|c|c|c|}
\hline Profession & Province & 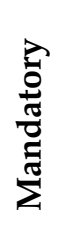 & 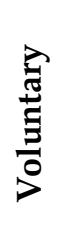 & 叫 \\
\hline \multirow{13}{*}{$\begin{array}{l}\text { Medical Radiation } \\
\text { Technologists }\end{array}$} & British Columbia & & $X$ & $\begin{array}{c}\text { not } \\
\text { applicable }\end{array}$ \\
\hline & Alberta & & $x$ & $\begin{array}{c}\text { not } \\
\text { applicable }\end{array}$ \\
\hline & Saskatchewan & & $X$ & $\begin{array}{c}\text { not } \\
\text { applicable }\end{array}$ \\
\hline & Manitoba & & $x$ & $\begin{array}{c}\text { not } \\
\text { applicable }\end{array}$ \\
\hline & Ontario & $X$ & & yearly cycle \\
\hline & Québec & & $x$ & $\begin{array}{c}\text { not } \\
\text { applicable }\end{array}$ \\
\hline & New Brunswick & & $x$ & $\begin{array}{c}\text { not } \\
\text { applicable }\end{array}$ \\
\hline & Nova Scotia & & $X$ & $\begin{array}{c}\text { not } \\
\text { applicable }\end{array}$ \\
\hline & $\begin{array}{l}\text { Prince Edward } \\
\text { Island }\end{array}$ & & $x$ & $\begin{array}{c}\text { not } \\
\text { applicable }\end{array}$ \\
\hline & $\begin{array}{l}\text { Newfoundland } \\
\text { and Labrador }\end{array}$ & & $X$ & $\begin{array}{c}\text { not } \\
\text { applicable }\end{array}$ \\
\hline & $\begin{array}{l}\text { Northwest } \\
\text { Territories }\end{array}$ & & $X$ & $\begin{array}{c}\text { not } \\
\text { applicable }\end{array}$ \\
\hline & Nunavut & & $X$ & $\begin{array}{c}\text { not } \\
\text { applicable }\end{array}$ \\
\hline & Yukon & & $x$ & $\begin{array}{c}\text { not } \\
\text { applicable }\end{array}$ \\
\hline
\end{tabular}


Licensed Practical Nurses (LPNs)

Only British Columbia, Alberta, Saskatchewan, and Ontario have legislation that mandates licensed practical nurses participate in some form of CPE for re-registration (or re-licensure). Each year, over a five-year cycle, the College of Licensed Practical Nurses of British Columbia randomly chooses $20 \%$ of its registrants to participate in its continuing competency review. Currently, program registrants are required to complete and submit a practice questionnaire and maintain a professional portfolio. The College of Licensed Practical Nurses of Alberta and the Saskatchewan Association of Licensed Practical Nurses both require evidence of mandatory continuing education annually for re-registration. LPNs who work in Ontario are subject to the same regulations and legislation as registered nurses. They are regulated and monitored by the College of Nurses of Ontario and must participate in its reflective practice program in order to be re-registered.

\section{Pharmacists}

With the exception of the three territories and the province of Québec, all other Canadian provinces have legislation that mandates pharmacists' participation in some form of CPE for re-licensure. The nature of these CPE systems varies by province. Some of these systems take the form of continuing competency programs that are self-directed in nature; others mandate the completion of a specific number of continuing education units (CEUs). The length of cycles for meeting CPE requirements ranges from one to six years across these different jurisdictions. Each province's professional association or body monitors the continuing education system to ensure members meet $\mathrm{CPE}$ requirements at the time of re-licensure. A yearly submission of members' professional development logs, learning records, CEU transcripts, etc., is required. Random audits are conducted to confirm compliance in some instances.

Psychologists

The Canadian Psychological Association's Code of Ethics states that psychologists should "participate in and contribute to continuing education and the professional and scientific growth of self and colleagues" (Canadian Psychological Association, 2000). However, only British Columbia, Ontario, and Prince Edward Island have legislation that requires psychologists to participate in some form of CPE for re-licensure purposes. The College of Psychologists of British Columbia has implemented a continuing competency program that mandates psychologists complete 35 hours of CPE per year. The College of Psychologists of Ontario requires members holding a Certificate of Registration to complete a self-assessment guide and professional development plan every other year. In both provinces, members must

Revue canadienne de l'éducation permanente universitaire

Vol. 32, No 1, primtemps 2006 
submit a signed declaration that they have completed the required program components. Random audits are conducted to confirm compliance with the regulations. The Prince Edward Island Psychologists Board requires its members to complete 40 hours of CPE per year.

Social Workers

The Canadian Association of Social Workers (CASW) recommends that social workers participate in 40 hours of continuing professional development each year. Alberta, Saskatchewan, Manitoba, New Brunswick, Nova Scotia, and Newfoundland and Labrador mandate that social workers participate in some form of CPE for re-licensure. Each of these provinces adheres to the national CASW standard and, in general, most accept both formal and informal methods of CPE. The other provinces and the three territories do not require $\mathrm{CPE}$ for re-licensure purposes.

\section{Occupational Therapists}

None of the territories and, of the provinces, only Ontario and Prince Edward Island have legislation mandating occupational therapists participate in some form of CPE for re-licensure. The College of Occupational Therapists of Ontario (COTO) requires its members to participate annually in a quality assurance program. This entails completing a self-directed prescribed regulatory education program (PREP) module and a self-assessment tool, as well as compiling a professional portfolio that details their professional development activities, after which they must complete the quality assurance declaration on the annual registration form. COTO also conducts random competency review and evaluation audits. The Prince Edward Island Occupational Therapists Registration Board requires its members to obtain $10 \mathrm{CPE}$ credits annually. Members must submit a list of their CPE activities with their annual application for re-registration.

\section{Physiotherapists}

Physiotherapists do not require CPE for licensure renewal in British Columbia, Alberta, Saskatchewan, Manitoba, Québec, New Brunswick, Nova Scotia, and Newfoundland and Labrador, nor in Northwest Territories, Nunavut, and Yukon. However, British Columbia, Alberta, Saskatchewan, and New Brunswick are developing or are finalizing continuing competence programs. Prince Edward Island and Ontario have legislation that mandates physiotherapists participate in some form of CPE for re-licensure. The Prince Edward Island College of Physiotherapists requires its members to obtain 10 CPE credits annually and to submit a list of their CPE activities with their application for re-licensure. Ontario physiotherapists must maintain a learning portfolio on an annual basis that demonstrates evidence of their ongo-

Canadian Journal of University Continuing Education

Vol. 32, No. 1, Spring 2006 
ing learning. The monitoring structure is self-reporting; participants sign a declaration on their annual renewal form signifying they have maintained a professional portfolio. Approximately $10 \%$ of Ontario registrants are audited each year.

\section{Medical Laboratory Technologists}

Only Saskatchewan, Ontario, and Nova Scotia mandate medical laboratory technologists participate in $\mathrm{CPE}$ for re-licensure. The nature and length of the CPE cycles vary across these jurisdictions, ranging from one to five years. $\mathrm{CPE}$ is not required for re-licensure in the other provinces or in the territories, but several voluntary CPE programs are available through both provincial and national organizations. The Alberta College of Medical Laboratory Technologists has a voluntary professional development program, which requires participants to obtain 4 credits in a two-year period. The Canadian Society for Medical Laboratory Science offers two voluntary professional recognition programs. Its professional enhancement program requires members to complete 60 hours of professional development over two years. Acceptable activities include, but are not limited to, continuing education courses, presentations (e.g., scientific paper or lecture), editorial work, book reviews, serving on exam panels, or attending national or provincial conferences. The society's certificate of continuing professional studies formally recognizes medical laboratory technologists' successful completion of continuing education courses at an advanced level.

\section{Medical Radiation Technologists}

Only Ontario requires CPE for renewal of licensure. The College of Medical Radiation Technologists of Ontario (CMRTO) requires members to participate in its quality assurance program on an annual basis. The program consists of a self-assessment profile, a continuous learning portfolio (which must demonstrate a minimum 25 hours of continuous learning activities), and a certificate of competence (a quality-assurance declaration). CMRTO does not have a list of approved courses, thus members are free to choose which activities will be part of their learning portfolios. The only guideline is that activities must relate to improving the member's knowledge, skill, and judgment as a medical radiation technologist. Members are required to submit their completed certificate of competence along with their annual registration renewal. Randomly selected members are asked to submit their selfassessment profiles and continuous learning portfolios (or portions of them) for review on an annual basis.

Voluntary CPE programs are available at the provincial level. Both the British Columbia Association of Medical Radiation Technologists and the Saskatchewan Association of Medical Radiation Technologists have voluntary programs in place.

Revue canadienne de l'éducation permanente universitaire

Vol. 32, No 1, primtemps 2006 


\section{Continuing Professional Education Providers}

Survey respondents were asked to identify the different providers of continuing professional education in their respective CPE systems. In this context, CPE providers referred to those who plan, develop, implement, and provide formal CPE courses, programs, workshops, and other activities to members of a particular health profession. The responses were similar across professions. Academic institutions (e.g., universities or community colleges), national and provincial associations, national and provincial regulatory bodies, hospitals and/or other health care employers (e.g., long-term-care facilities), government, and private industry (e.g., pharmaceutical and communications companies) were identified as important providers of CPE to members of their profession.

\section{Discussion AND Conclusion}

National systems of mandatory continuing professional education were found to exist for family physicians, medical specialists, and speech language pathologists and audiologists. These particular CPE systems are regulated and monitored by a national professional body and based on re-certification, not re-licensure. The national CPE system for speech language pathologists and audiologists is mandatory for those practitioners who belong to the national association. The national system for family physicians and medical specialists is based on re-certification only; therefore, only those individuals who are members of the College of Family Physicians of Canada or the Royal College of Physicians and Surgeons of Canada are mandated to participate in CPE. The review did not uncover a national CPE system that was linked directly to re-licensure across jurisdictions.

The voluntary, versus mandatory, nature of CPE systems for the professions of nursing, pharmacy, psychology, social work, occupational therapy, physiotherapy, medical laboratory technology, and medical radiation technology varied across provincial jurisdictions. Some professions have wellestablished or developing systems of CPE across the provinces. Nursing and pharmacy have well-organized CPE systems in place across the country and, although the specific aspects of the systems vary across provinces, most were based on mandatory requirements.

The nursing profession demonstrated an innovative and flexible approach to mandated CPE participation. Its CPE systems have moved away from "clocked" hours as proof of attendance or participation in CPE activities toward continuing competency programs in which participants are given greater flexibility and autonomy to identify their learning needs and select and pursue CPE activities that meet these needs. In most instances, nursing professionals must maintain a personal learning plan of some sort and, 
through this, demonstrate how they have reflected on their professional development needs and undertaken CPE activities to address them.

For the pharmacy profession, the majority of provinces had mandatory $\mathrm{CPE}$ systems in place that were linked to re-licensure. The nature of these systems varied across the provinces. Some provinces have self-directed CPE systems in the form of continuing competency programs; others mandate the collection of a specific number of continuing education units (CEUs). Each province's professional association or body monitors the system to ensure CPE requirements are met at the time of re-licensure. Annual submission of professional development logs, learning records, CEU transcripts, etc., is required in some jurisdictions. Random audits are conducted to confirm compliance in some instances.

The social work profession has a developing system of CPE across provincial jurisdictions. The Canadian Association of Social Workers (CASW) recommends that their members maintain a participation standard of 40 hours of continuing professional development each year. Presently, six provinces mandate social workers to participate in some form of CPE for re-licensure; each of these provinces adheres to the national CASW standard.

The majority of provinces did not have a mandatory CPE system in place for either the occupational therapy or the physiotherapy profession. Each profession's national association has undertaken some preliminary work on professional development principles and guidelines. As well, several provincial regulatory bodies are developing or are finalizing mandatory systems in which some form of CPE will be required.

The comparative summary presented here raises some important considerations about the introduction of mandatory continuing education systems. One key consideration is the organizational and resource requirements for administering and monitoring such a system. If mandatory CPE is introduced, who is responsible for administering the system and where do the resources come from to do this? Are there legislative ramifications that would require changes and modifications to implement mandatory systems? What are the financial implications for the professionals, and their employers, in terms of paying for and funding participation in CPE activities? Another key consideration involves access to CPE, particularly for professionals in rural and remote areas. Providing CPE to rural and remote-area health professionals is a challenge due to geographic isolation and its associated costs, such as program development and delivery expenditures and funding for travel. A third consideration relates to the availability of health professionals to participate in mandatory CPE and the practical implications of this for employers. This is particularly significant for health professionals who work irregular shifts.

Revue canadienne de l'éducation permanente universitaire

Vol. 32, No 1, primtemps 2006 
The formal accreditation of CPE programs and providers also had significance for several of the CPE systems reviewed. If a regulatory body requires program accreditation/approval, then only accredited or approved CPE programs (in general, programs that meet specified criteria and standards) will meet CPE requirements for re-certification or re-licensure. In turn, CPE providers must also be accredited (in general, providers must meet minimum standards outlined by a CPE system accrediting body) in order to design, plan, and organize accredited CPE programs. This has important implications for CPE providers attempting to offer programs across provincial jurisdictions, which could have differing CPE provider or program accreditation standards.

The use of distance learning technologies and the design of self-directed learning systems for mandatory CPE are examples of best practices for enhancing access to CPE activities. Cervero (2000) suggested that a major trend in continuing professional education is the increased number of programs being offered in distance education formats. The use of information and communication technologies for CPE delivery is particularly useful for increasing access for rural and remote-area health professionals (Curran \& Noseworthy, 1999; Mattheos, Schittek, Attstrom, \& Lyon, 2001). Distance learning can be used to overcome barriers of distance and cost (Sheppard \& Mackintosh, 1998) and barriers that compromise access to CPE. The Pearls ${ }^{\mathrm{TM}}$ program of the College of Family Physicians of Canada is an example of a CPE learning model that enables physicians to undertake a self-directed learning project, based on their practice needs, and receive accredited continuing medical education credit.

Greater collaboration between inter-professional and inter-sectoral groups is another noteworthy strategy for increasing access to CPE activities. A number of stakeholder groups and organizations might benefit from the formation of different partnerships for the delivery of CPE. Examples of these groups include professional associations, employers, community agencies, universities, health districts, industry, hospitals, unions, and vendors/companies. Cervero (2000) indicated a further trend in CPE: the growth in collaborative arrangements among providers, especially between universities and workplaces.

The study findings indicated that a national, mandatory CPE system exists and is a key component of re-certification for one of the largest health professional groups in Canada-family physicians and medical specialists. The nursing and pharmacy professions have well-established CPE systems at provincial levels, with varied requirements across jurisdictions, and the social work profession is developing a mandated CPE system in a number of provinces. The CPE systems for the other health professions and the health 
provider groups examined in this review were less developed across provincial jurisdictions.

The reviewed systems also exhibited a mix of characteristics from the update and competence models, as described by Nowlen (1988). The national CPE systems for family physicians and medical specialists, as well as the majority of provincial CPE systems for registered nurses, demonstrated the major characteristics of the competence model. Other CPE systems illustrated features of the update model, with a small number of specific jurisdictions requiring some form of professional self-assessment, a characteristic of Nowlen's performance model.

Overall, the review suggested that there is a growing emphasis on developing mandatory CPE across professions and provincial jurisdictions in Canada. Thus, providers of CPE may have exciting opportunities to establish new partnerships and expand programs to reach new target audiences.

\section{REFERENCES}

Brockett, R. G., \& LeGrand, B. F. (1992). Part Five: Should continuing education be mandatory? New Directions for Adult and Continuing Education, 54, 85-103.

Byers, D. L., Hilgenberg, C. S., \& Rhodes, D. M. (1996). Evaluation of interactive television continuing education programs for health care professionals. Journal of Educational Technology Systems, 24(3), 259-270.

Canadian Psychological Association. (2000). Canadian code of ethics for psychologists: Principle IV.4. Retrieved October 13, 2004 from http://www.cpa. ca/ethics2000.html.

Cervero, R. M. (2000). Trends and issues in continuing professional education. New Directions for Adult and Continuing Education, 86, 3-12.

Curran, V. R., \& Noseworthy, T. (1999). Distance learning and the health professions: A synthesis report of the literature investigating continuing health professional education at a distance. Columbus, OH: ERIC Clearinghouse on Adult, Career, and Vocational Education, ED 461740.

Davis, D. A., Thomson, M. A., Oxman, A. D., \& Haynes, R. B. (1995). Changing physician performance: A systematic review of the effect of continuing medical education strategies. Journal of the American Medical Association, 272, 700-705.

Grossman, J. (1998). Continuing competence in the health professions. The American Journal of Occupational Therapy, 52(9), 709-715.

Revue canadienne de l'éducation permanente universitaire

Vol. 32, No 1, primtemps 2006 
Houle, C. O. (1980). Continuing learning in the professions. San Francisco: Jossey-Bass.

Kerka, S. (1994). Mandatory continuing education. ERIC Digest No. 151. Columbus, OH: ERIC Clearinghouse of Adult, Career and Vocational Education, ED376275.

Latchem, C., \& Rapley, P. (1992). Trial by satellite: Video conferencing for continuing education for rural area nurses. Distance Education, 13(1), $118-130$.

Leggate, M., \& Russell, E. (2002). Attitudes and trends of primary care dentists to continuing professional development: A report from the Scottish Dental Practitioners Survey 2000. British Dental Journal, 193(8), 465-469.

Little, C. D. (1993). Mandatory continuing education. Journal of Continuing Education in the Health Professions, 13(2), 159-167.

Mattheos, N., Schittek, M., Attstrom, R., \& Lyon, H. C. (2001). Distance learning in academic health education: A literature review. European Journal of Dental Education, 5, 67-76.

Mott, V. W. (2000). The development of professional expertise in the workplace. New Directions in Continuing Education, 86, 23-31.

Mott, V. W. (1998). Professionalization and reflective theory building in HRD. Proceedings of the Academy of Human Resource Development, Washington, DC, March 5-8, 1998.

Nowlen, P. M. (1988). A new approach to continuing education for business and the professions. Old Tappan, NJ: Macmillan.

Queeney, D. S., \& English, J. K. (1994). Mandatory continuing education: A status report. Columbus, OH: ERIC Clearinghouse on Adult, Career and Vocational Education.

Sheppard, L., \& Mackintosh, S. (1998). Technology in education: What is appropriate for rural and remote allied health professionals? Australian Journal of Rural Health, 6, 189-193. 


\section{APPENDIX A}

\section{Interview Script}

\section{Definition of Continuing Education}

Continuing education is defined as the participation in formal, informal, or non-formal learning activities that are organized or self-directed in nature, occur after completion of pre-professional education for licensure or practice, and may be voluntary or mandatory.

Mandatory continuing education (MCE) is required by a licensure board, professional organization, or workplace in order to maintain competence and retain licensure, certification, and/or employment.

\section{General Nature of CE System}

What is the nature of the continuing education system in Canada for your profession/field of practice?

Prompt: Is there a formalized system of continuing education?

Prompt: Is the CE system: $\square$ mandatory $\square$ voluntary

MCE is required in order to maintain certification or licensure to practise in a health profession or health care field.

\section{Mandatory $C E$}

Is the CE system regulated at a $\square$ national or $\square$ provincial level?

What body is responsible for its regulation?

- National level:

- Provincial level:

What are the mandatory CE requirements for professionals or individuals in your field of practice?

Prompt: \# of CE units/hours per year 
How is participation in mandatory CE monitored by your profession/field of practice?

Prompt: What is the structure of this monitoring?

Prompt: How is this monitoring organized?

- National level:

- Provincial level:

What are some of the factors influencing the implementation of MCE in your profession/field of practice?

\section{CE Providers}

Who are the CE providers in your continuing education system?

Are providers required to be accredited to offer CE?

$\square$ yes

$\square$ no

Who accredits providers?

What is the nature of the accreditation process?

How often does accreditation occur? 


\section{APPENDIX B}

\section{Web Survey}

Thank you for completing this survey, which is a key component of a study of the continuing education system for health care providers in Canada. This study is funded by the Health Human Resource Strategies Division, Health Canada, and is being conducted by the Office of Professional Development, Faculty of Medicine, Memorial University of Newfoundland.

The survey should take no longer than 10 minutes of your time to complete. All information gathered through the study will be anonymous and reported in aggregate manner, with no identifying information.

Sincerely,

Vernon Curran, $\mathrm{PhD}$

Director of Research and Development

\section{Definition of Continuing Education}

Continuing education is defined as the participation in formal, informal, or non-formal learning activities that are organized or self-directed in nature, occur after completion of pre-professional education for licensure or practice, and may be voluntary or mandatory.

Mandatory continuing education is required by a licensure board, professional organization, or workplace in order to maintain competence and retain licensure, certification, registration, and/or employment.

\section{Section 1:}

1. What organization, institution, body, or association do you represent (e.g., Memorial University School of Nursing; Ontario Medical Association; BC Society of Laboratory Science)?

2. What is the nature of the continuing education system in your province for your profession/discipline/field of practice?

- Mandatory (Mandatory CE is required in order to maintain certification, registration, or licensure to practise in a health profession or health care field.) If mandatory, go to Section 2.

V Voluntary If voluntary, go to Section 3.

Revue canadienne de l'éducation permanente universitaire Vol. 32, No 1, primtemps 2006 
The Characteristics of Continuing Professional Education Systems ...

\section{Section 2: Mandatory CE}

3. Is the Mandatory CE system for your province regulated at a national or provincial level?

\section{口 National}

If national, what organization, institution, body, or association is responsible for its regulation?

\section{口 Provincial}

If provincial, what organization, institution, body, or association is responsible for its regulation?

4. What are the mandatory $\mathrm{CE}$ requirements for your province? \# of CE units/hours per year (please describe)

5. Are CE activities required to be accredited/approved/endorsed in order to be counted toward mandatory $\mathrm{CE}$ requirements?

口 Yes

If yes, what organization, institution, body, or association is responsible for program accreditation/approval/endorsement?

$\square$ No

If no, please explain.

6. How is participation in mandatory CE monitored in your province? (Check all that apply.)

Regular submission of record(s)/transcripts of CE participation

Random individual practitioner audit(s)

$\square$ Other 
7. What organization, institution, body, or association is responsible for administering and managing this monitoring process?

8. Who are the CE providers in your continuing education system? (Check all that apply.)

$\square$ Universities

$\square$ Community Colleges

Employers/Hospitals

口 Professional Association

Licensing body

u Union

Specialty Societies

$\square$ Industry

- Health/patient advocacy agencies (e.g., Canadian Cancer Society)

$\square$ Self-Directed by individuals

O Other:

$\square$ Other:

O Other:

9. Are $\mathrm{CE}$ providers required to be accredited/approved/endorsed to offer CE?

$\square$ Yes

If yes, what organization, institution, body, or association is responsible for accrediting/approving/endorsing providers?

$\square$ No

If no, please explain.

Revue canadienne de l'éducation permanente universitaire

Vol. 32, No 1, primtemps 2006 
The Characteristics of Continuing Professional Education Systems ...

\section{Section 3: Voluntary CE}

10. Is the Voluntary CE system for your province managed/administered at a national or provincial level?

\section{National}

If national, what organization, institution, body, or association is responsible for its management/administration?

\section{Provincial}

If provincial, what organization, institution, body, or association is responsible for its management/administration?

11. What are the voluntary CE requirements for your province?

\# of CE units/hours per year (please describe)

12. Are CE activities required to be accredited/approved/endorsed in order to be counted toward voluntary $\mathrm{CE}$ requirements?

$\square$ Yes

If yes, what organization, institution, body, or association is responsible for program accreditation/approval/endorsement?

No

If no, please explain.

Canadian Journal of University Continuing Education

Vol. 32, No. 1, Spring 2006 
13. Who are the CE providers in your continuing education system? (Check all that apply.)

$\square$ Universities

Community Colleges

Employers/Hospitals

Professional Association

Licensing body

U Union

$\checkmark$ Specialty Societies

$\square$ Industry

Health/patient advocacy agencies (e.g., Canadian Cancer Society)

$\square$ Self-Directed by individuals

O Other:

Other:

O Other:

14. Are providers required to be accredited to offer CE?

$\square$ Yes

If yes, what organization, institution, body, or association is responsible for accrediting/approving/endorsing providers?

$\square$ No

If no, please explain.

Thank you for completing this survey.

Revue canadienne de l'éducation permanente universitaire Vol. 32, No 1, primtemps 2006 


\section{BIOGRAPHIES}

Vernon Curran is director of academic research and development and an associate professor of medical education with the Faculty of Medicine, Memorial University, Newfoundland. He also teaches in undergraduate and graduate degree programs in adult education and post-secondary studies with the Faculty of Education. His areas of research specialization include professional health education, tele-education, continuing professional education, and inter-professional education in the health professions.

Vernon Curran est directeur de recherche universitaire et de développement ainsi que professeur agrégé en éducation médicale de la Faculté de la médecine à l'Université Memorial de Terre-Neuve. Il enseigne aussi dans les programmes universitaires de premier et de deuxième cycle en éducation des adultes et postsecondaire à la Faculté de l'éducation. Parmi ses domaines de spécialisation en recherche se retrouvent la formation des professionnels de la santé, l'enseignement à distance, l'éducation professionnelle permanente et l'éducation interprofessionnelle dans les professions de la santé.

Fran Kirby is director, professional development and conferencing solutions, Faculty of Medicine, Memorial University, Newfoundland. She is responsible for leading continuing professional development for physicians and health professionals, distributed learning using ICTs, and the development of public/private sector partnerships. Kirby is a member of the board of the Canadian Association for Continuing Health Education (CACHE) and has successfully developed and led pan-Canadian initiatives, like the MDcme.ca web portal.

Fran Kirby est directrice du développement professionnel et des solutions d'entretien à la Faculté de la médecine, à l'Université Memorial de Terre-Neuve. Elle est responsable de mener le développement professionnel permanent des médecins et des professionnels de la santé, de l'apprentissage distribue à l'aide des TIC, et du développement de partenariats dans les secteurs public et privé. Kirby est membre du comité de l'Association canadienne d'éducation médicale continue (ACÉMC) et a développé et mené des initiatives pancanadiennes avec succès, dont le portail Web MDcme.ca.

Lisa Fleet is a research coordinator with the Faculty of Medicine, Memorial University, Newfoundland. She has almost six years' experience in an educational and research environment. Fleet coordinates and conducts research and development activities related to health professional education and professional development at both provincial and national levels.

Canadian Journal of University Continuing Education

Vol. 32, No. 1, Spring 2006 
Lisa Fleet est coordonnatrice de recherche à la Faculté de la médecine, à l'Université Memorial de Terre-Neuve. Elle a près de six ans d'expérience dans un environnement d'éducation et de recherche. Fleet coordonne et effectue des activités de recherche et de développement reliées à la formation des professionnels de la santé et au développement professionnel à la fois au niveau provincial et au niveau national. 